\title{
The Prospects of the ICT Policy Framework for Rural Entrepreneurs: an analysis of the Relationship between ICT and Entrepreneurial Development
}

\author{
*Maramura Tafadzwa Clementine, Elvin Shava \\ North-West University, Vanderbijlpark, South Africa \\ *tmaramura@gmail.com, ellyshava@gmail.com
}

\begin{abstract}
Entrepreneurs hold the keys to rapid technological development by offering the means to creating employment opportunities even in remote rural areas. Small entrepreneurs do not only provide livelihood for themselves, but they also create employment thereby easing up socio-economic tensions in an atmosphere where so many are deprived. This article introduces the concept of entrepreneurship and how it propagates development and advances human living conditions. The underlying assumption is that Information and Communication Technology (ICT) has a causal effect on human livelihoods of rural entrepreneurs. Thus, a sturdy relationship exists between ICT and entrepreneurial development for rural entrepreneurial economic growth. In the same manner the Government of Zimbabwe commenced on a comprehensive policy framework in order to harness the power of ICT. Through a documentary review analysis, the paper envisages how ICT can sustain rural entrepreneurial development in Zimbabwe at a time where it is suffering from harsh socio-economic and political turmoil. The paper observes that lack of financial services, corruption, political interference, poor planning and the desire to maintain status quo have been discouraging rural entrepreneurship to harness the benefits of ICT. The paper recommends that the government should implement policies that promote the development of ICT in rural entrepreneurship and the provision of training and development for entrepreneurs to bridge the knowledge gap on the use of ICT to enhance the livelihoods of entrepreneurs.
\end{abstract}

Keywords: Entrepreneurship, Entrepreneurial Development, ICT Policy Framework, Rural Entrepreneurs

\section{Introduction}

The rationale behind this paper is to achieve the primary objective of the use of ICT for its direct contribution to rural entrepreneurial growth towards the overall national socio-economic agenda. According to the World Bank (2012), a 10\% increase in ICT penetration causes a 1,38\% in gross development product contribution (GDP). In 2013 ICT contributed 15, 2\% to Zimbabwe's GDP (World Bank, 2013). According to the 2015 National Budget, the forecast of ICT growth for entrepreneurial development was 6.4\% (Chimucheka, 2015). The study was driven by the amass benefits of ICT development that still need to be cultivated among rural entrepreneurs in Zimbabwe. The power of ICT needs to be injected into the entrepreneurial ecosystem to sustain and maintain the levels of development, considering ICT catapults sectoral development and growth (Ndemo, (2015). According to Zimmerman (2008) the study of entrepreneurship became of prominent interest for policy makers in many nations during the $21^{\text {st }}$ century which has been regarded as the information age. Entrepreneurship has since been regarded as the economic engine necessary for accelerating economic growth, poverty reduction and job creation, bearing in mind the economic meltdown that has strongly hit Zimbabwe (Chimucheka, 2015). Entrepreneurial development becomes very crucial for any developing economy, in particular Zimbabwe's. Simultaneously, the use of ICT is accelerating with new products and new production methods and it has transformed the universe into one globe by creating a global market-place for all businesses through the implementation of various ICT strategies. Zimbabwe is still attempting to harness ICT for entrepreneurial development, as outlined in the World Summit on the Information Society (WSIS) Declaration of Principles and Plan of Action (Geneva in 2003 and Tunis in 2005), Heads of States and governments in developing nations were urged to adopt the use of ICT in order to achieve developmental goals (Zimmerman, 2008).

Background: According to Doyle (2008) ICT directly points to any device or system that allows for the storage, retrieval, manipulation, transmission and receipt of digital information. This means that computers, 
scanners, systems soft ware's, databases and word processors all encompass ICT. It is significant to comprehend that ICT is not only about computers because the " $\mathrm{C}$ " in the ICT is for communication, which covers all forms of communication and the "T" for technology; which is inclusive of internet, global positioning systems and broadband (Doyle, 2008). Entrepreneurship is a way of thinking, reasoning and acting that is opportunity based, holistic in approach and leadership balanced (Timmons \& Spinelli, 2004). This simply implies that entrepreneurs are responsible for the establishment of an enterprise and for this enterprise to thrive, a strong supporting entrepreneurial system is key to the success of that particular enterprise. Resultantly, the concept of entrepreneurship basically indicates to the creation of an enterprise in response to an identified opportunity for profit making by a rural entrepreneur (LSBM, 2016). Entrepreneurship development is the process of enhancing entrepreneurial skills and knowledge through structured training and institution-building programs (LSMB, 2016). It aims to enlarge the base of entrepreneurs in order to hasten the pace at which new ventures are created, which is aimed at accelerating employment generation and economic development (Nieman and Nieuwenhuizen, 2009). The assumption is that urban entrepreneurs tend to enjoy the fruits of entrepreneurial development more than their rural based counterparts who do not have sustainable entrepreneurial ecosystems to promote entrepreneurial development within their enterprises. In addition, studies show that in Zimbabwe the urban to rural ratio of entrepreneurs is 1, 8:1 as opposed to 1:1 for countries like Peru and Chile (Chimucheka, 2015). The most probable explanation for these figures is because rural based entrepreneurs do not have access to adequate infrastructural ICT systems most significantly which have the capacity to propel them to a higher level of entrepreneurial development.

Statement of the Problem: The problem is that although the Zimbabwean government has embarked on ICT development, in the form of policy frameworks enabled through mobile phones, telephones, radios, televisions and internet as ways of improving rural entrepreneurs. It still remains unclear whether rural entrepreneurs are benefiting and to what extent they are enjoying the benefits. The benefits that the rural entrepreneurs should expect are efficient and effective communication systems for socio-economic development and easy affordable and fast access to information for entrepreneurial development (Ndemo, (2015). This is because ICT aims to provide invaluable input to creating and sustaining entrepreneurship. Hence it is fundamental to determine the direct impact of ICT advancement on the livelihoods of the rural entrepreneurs in Zimbabwe. Private companies that include Net One and Econet have erected cell phone boosters in rural areas to place ICT within the reach of the populations in the remote rural areas of Zimbabwe. According to Chisita (2010) Econet launched 3G technology which allows subscribers to access internet on their mobile phones, which will certainly assist entrepreneurs to employ e-services and ebusiness to boost their enterprises. This is because experience from successful emerging economies in Africa, Asia and Latin America shows that a vibrant sector of rural entrepreneurs and a fertile ground for entrepreneurial minds as driven by ICT play a key role in the economic growth of developing nations (Ndemo, 2015).

The National ICT Policy Framework: Upon the realization of the potential of ICT, the government of Zimbabwe formulated the National ICT Policy Framework in 2005 and a review of the policy was amended in May 2012 due to the rapid changes in the development of ICT. The vision of this policy is to transform Zimbabwe into a knowledge-based society by 2020 and the mission is to accelerate the development and application of ICT in support of sustainable socioeconomic growth and development in the country (Zimbabwe National ICT policy Framework 2012). This clearly streamlines the prospects of ICT for the entrepreneurial development of rural entrepreneurs, if the ICT policy framework of 2012 is meant to sustain the socio-economic growth of citizens. This is explained by the policy framework which is meant to guide and direct the formulation and implementation of ICT strategies and programmes in Zimbabwe. The main function of the national ICT policy is to develop suitable programs and strategies which promote ICT advancement. This is why the policy seeks to lead in the development of proper regulatory frameworks which promote ICT (Government of Zimbabwe, 2012). Another function of the ICT policy is to encourage awareness in the promotion of ICT usage in the country so that the citizens can be competitive in the region and resultantly the rural based entrepreneurs can also thrive, (Zimbabwe National ICT policy Framework 2012). Most importantly this directly points to the rural based entrepreneurs whose awareness to ICT is relatively low which limits their direct exposure to entrepreneurial development (Chisita, 2010). 
Although ICT plays an influential role in the economy and assists in turning-around the economy of the country, ICT does not yet play such a role in the rural population of Zimbabwe (Sander, 2008). If a robust ICT policy could be implemented by digitalizing the rural entrepreneurs then weak utilization of ICT systems would be eradicated. The Global Entrepreneurship Monitor (GEM, 2011) estimated that 388 million entrepreneurs were actively engaged in starting and running new businesses around the globe, and 165 million of them were rural early-stage entrepreneurs between the ages of 18 and 35. Considering staggering global unemployment levels, much hope for the rural population lies in their ability to become job creators rather than job seekers. It is becoming easier for entrepreneurs to find the information they need to start their own businesses, and an increasing number of government initiatives are helping to make the process quicker and less costly (LSBM, 2016). Resultantly, the number of mobile subscriptions in use worldwide both pre-paid and with contracts, has grown from 1 billion in 2000 to over 6 billion and five billion of those live in developing nations (Ndemo, 2015).

\section{Literature Review}

The absence of sustainable ICT strategies has been identified as causing low productivity for rural entrepreneurial development in developing countries such as Zimbabwe (Chimucheka, 2015). Zimbabwe has a lot to learn from other developing countries that have incorporated ICT to promote entrepreneurial development with the inclusion of Kenya, India, and Ghana which have managed to successfully implement ICT policy frameworks (Nwagu, 2006). If harnessed well, ICT does have a strong direct impact on the lives of the rural based entrepreneurs for entrepreneurial development. The Minister of Information and Technology for Zimbabwe indicated that Zimbabwe is one of the poorest countries in Sub-Saharan Africa that has the lowest access to information and communication resources (Zimbabwe National ICT policy Framework 2012). Tied to the fact that Zimbabwe as a country has very limited access to ICT resources in sub-Saharan Africa, this limits and restricts the rural based entrepreneur who is the last link on the entrepreneurial chain amidst all the turmoil and mayhem the nation is encountering. To rectify this predicament, the national ICT policy framework was implemented as a measure to reduce social, political and economic inequalities which are tearing through the entrepreneurial fabric of Zimbabwe. Ndemo (2015) asserts that developing countries which have harnessed the potential of ICT managed to emerge with better strategies aimed at rural entrepreneurial development, equity in the distribution of resources, social transformation and poverty reduction. Nwagu (2006) gives a striking example of the Asian Pacific economies which managed to improve their economic growth and competitiveness through modernized production systems, propagated through the implementation of ICT strategies. Hong Kong, Singapore and Taiwan's modernized production systems also improved the capabilities of their economies by promoting rural entrepreneurial development (Nwagu, 2006). This implies that if the use of ICT in developing nations is properly managed and retained it benefits the rural entrepreneurs and in turn boosts economic growth for the promotion of rural livelihoods.

Zimbabwe as a "Failed State": WB (2015) defines failed states as "those where the state in power is unable and unwilling to deliver core functions to the majority of its people in terms of security, protection of property rights, basic public services and essential infrastructure". Fesler (1968) defines a failed state as one "wherein the government cannot or will not provide an environment for households to reduce, mitigate or cope with poverty and other risks to well-being". State failure is one of the critical causes of failed relationship between ICT and entrepreneurial development. Therefore, it is essential to analyse the sustainable implementation of ICT policy frameworks in a broader frame of a probable regime change in Zimbabwe. Pending the status of Zimbabwe as a failed state, it is not just a matter of the prospects of the ICT policy frameworks for rural entrepreneurs but economic growth and poverty reduction as well. Zimbabwe has been, and is currently in a state of a complete meltdown in all its socio-economic and political facets since 2000 to date (2016) (Nhema and Zinyama, 2016). The Mugabe administration was primarily meant to embody every ideal that promoted the effective governance of Zimbabwe in the post-1980 era but the state is now fully incapacitated due to endemic government corruption and economic failure (Gambe, 2015). Zimbabwe's classification as a failed state is undeniable, as the country ranks number 16 globally on the Foreign Policy's Failed States Index of 2016 with a score of 100.5 (Nhema and Zinyama 2016). A number of factors may have contributed to this poor performance, in particular the contributing factors to the weak relationship between the ICT policy framework and rural entrepreneurial growth (Matabvu, 2016). 


\section{Theoretical Framework}

Technology Acceptance Model (TAM): Davis (1989) asserts that with the TAM model when "a user is presented with new technology, a number of factors influence their decision regarding how and when they will use it" (ANAO, 2009). The TAM has proven to be a robust model that is frequently used to study the user acceptance of ICT and it is widely used to help understand the adoption and use of internet ((ANAO, 2009). The theory helps to understand how adopters come to accept or reject the use of ICT in their small businesses. The TAM model proposes that certain factors will determine if a user will accept and use a technology, once it has been presented to them. These factors are:

- Perceived usefulness (PU): the extent to which the user believes that using a system enhances performance and satisfies needs determine if they will accept and use it again.

- Perceived ease of use (PEOU): this is the degree to which the user believes that using a certain system would be free of effort (ANAO, 2009).

These two factors guide the behavioral intention of users to use the system while the intention leads to actual use of the ICT. These factors are applicable to the rural entrepreneurs on the relationship that exists between them and the ICT policies and frameworks being implemented in Zimbabwe. Rural entrepreneurs should feel their productivity and efficiency improved by any means of technology. The main criticism of the theory is however that, the intention to use and the actual use of ICT innovation do not strongly link with each other. It is argued that the intention to use an ICT system does not necessarily mean that the rural entrepreneurs will actually use it. Hence strategic awareness should be done to ensure the benefits of ICT are cultivated by rural entrepreneurs (ANAO, 2009).

The Diffusion of Innovation (DOI) Theory: The Diffusion of Innovation Theory explains how, why and at what rate new ideas and technology spread through socio-economic systems over time. Rogers (1995) argues that ICT is communicated through channels via the process of diffusion and ICT diffusion is influenced by four main elements namely:

- The innovation itself

- Communication channel through which the innovation is diffused.

- Time

- A social system.

The process of innovation is strongly determined by human capital and for the ICT system to be sustained it has to be widely adopted (Gunday \& Ulusoy, 2011). The manifestation and sustainability of innovations vary from the subject to the nature of the adopters and how they perceive the ICT and adoption of the ICT is influenced by the following factors:

- Relative advantage - the degree to which the ICT system is perceived as being better than the idea, it is replacing.

- Compatibility - how consistent the innovation is with the values, norms and needs of the expected adopters.

- Complexity - how difficult the innovation is to understand and implement.

- Triability - how possible the innovation is to be tested before full commitment to its adoption

- Observability - what is the extent to which the innovation is capable of providing tangible results? (Gunday \& Ulusoy, 2011).

Both the Technology Acceptance Model and the Diffusion of Innovation theory have a direct causal link on the relationship that exists between the ICT policy frameworks and rural entrepreneurs for effective entrepreneurial development in Zimbabwe.

\section{Methodology}

The document study review was conducted for the Mhondoro which has 11 wards and is set up in a communal area situated in Chegutu District made up of commercial farms, small scale commercial farms as well as communal settlements. Muzenda and Muchawira (2012) explain that Mhondoro is in natural region III 
which is a semi-intensive farming region covering $19 \%$ of Zimbabwe. The rainfall in this region is moderate in total amount; severe mid-season dry spells make it marginal for maize, tobacco and cotton or for enterprises based on crop production alone. To this end, the farming systems are based on both livestock and assisted by the production of fodder crops and cash crops (Muzenda and Muchawira, 2012). Against this background the residents of Mhondoro have decided to stimulate rural development through ICTs in the hope that it will assist them in agriculture and in business hence rural entrepreneurs have been emerging to use ICT for sustainable development in the Mhondoro District of Zimbabwe. This study adopted a qualitative research approach based on a document study review to establish how rural entrepreneurs have been using ICTs for rural development in the district. Secondary analysis of published electronic journal articles together with relevant secondary data formulated the discussions and findings of this study on the current state of ICTs among rural entrepreneurs in Zimbabwe. Secondary analysis was conducted to provide an overview of the current state of ICTs in Mhondoro District in Zimbabwe. The data obtained from secondary sources was analysed in a qualitative manner using thematic content analysis of data. The reliability was exercised through using articles which were peer reviewed and those articles form the basis of this article.

\section{Findings}

Using documentary review analysis to explore on the use of ICTs in rural areas of Mhondoro in Zimbabwe, the study reveals that there are policy issues inhibiting the advancement of ICTs. These can be categorized into regulatory or political legislations in the country, poor infrastructural development and financial instability among rural entrepreneurs, social and political perceptions and poor monitoring and evaluation of ICT projects in rural communities

The challenges being faced by rural entrepreneurs-Inconsistent government policies: The bold initiative undertaken by the Zimbabwean government to advance the use of ICTs in rural areas of Zimbabwe is being highly appreciated. Documentary evidence reveals that some government measures, regulations or policies towards ICT service providers discourage the effective implementation by the rural populace. In the recent past, the government withdrew the operating license from TELECEL one of the contributing giant companies to ICTs in the country. Though no one can really establish the cause of such an action, the government was taken to court to answer for the withdrawal of the license. The study ascertained that such holistic antagonism on the government side has negative repercussions on most rural entrepreneurs who depend on cell phone networks to communicate in their business. Unstable government policies reverse the gains of World Summits such as Geneva to bring economic development to citizens through ICT development. These findings augur well with the study conducted in Nigeria by (Ihuba and Njoku, 2013). The results proved that change in governance policies affected the rural entrepreneurs since they did not have any control over such legislation.

High illiteracy rate among rural entrepreneurs: The advancement of ICTs in any country requires expertise to effectively use the highly technical devices. However, this study discovers that in Mhondoro, the use of ICT for rural economic growth has been hindered by high levels of illiteracy among the rural population. Most people presently residing in the rural areas are old people and those who could not get the opportunity to acquire education hence the use of ICT is a challenge for them. The study cannot ignore the fact that cell phones have been used by nearly everyone for primary reasons like making and receiving calls, but functions like internet browsing is still a long way to be achieved. The higher levels of illiteracy among rural entrepreneurs pose a serious challenge to both government and the private sector to conduct training and development workshops where most rural entrepreneurs can be educated on how to utilize modern technology such as computers, printers, tablets, scanners among others for their own benefit. Existing evidence indicates that there is much potential for rural entrepreneurs who are taught how to effectively operate the ICT systems because lives of millions of people can be enhanced. The First National Bank (2010) conducted a study in South Africa which corroborates these findings that ICT development is being discouraged by lack of education and insufficient social networking among rural entrepreneurs. This is a huge challenge for rural entrepreneurs in Mhondoro to meet and share ideas on how they can grow their business for rural economic development. 
Poor infrastructural development: The infrastructure in most rural communities in Zimbabwe is not conducive enough to advance the cause of rural entrepreneurs. While earmarked improvements have been realized in the form of rural electrification in some parts of the country, Mhondoro still lags behind as the infrastructure is failing to support the establishment of ICT systems to empower local people both technologically and economically. These findings were echoed by Greunen (2013) who affirmed that poor infrastructure is a barrier to effective development of ICT for socio and economic development. In another study Rasker et al. (2009) points out that, poor and underdeveloped infrastructure was singled out as a hindrance to the implementation of ICT for rural entrepreneurship. The study recognizes the unavailability of transport which is a stumbling block to rural entrepreneurs. A study was conducted by Gora and Fal (2010) in the Eastern Cape province of South Africa which is one of the poorest provinces to assess the viability of rural entrepreneurship using ICTs. Empirical evidence from this study points out that, persistent poverty coupled with poor infrastructure impair the success of rural entrepreneurship. In Zimbabwean context, Econet wireless the leading ICT brand, is trying in its capacity to assist rural entrepreneurs to grow in business given the establishment of a mobile bank, termed ECO-CASH. The majority of rural entrepreneurs from across the political and social divide embraced this initiative since it minimizes costs and risks associated with moving around with amounts of hard cash, as the financial transactions are done easily via mobile ECO-CASH. The need to improve on infrastructural development rests on the service providers of ICT such as Net One, Econet and Telecel to forge mutually beneficial partnerships with the government to establish infrastructural support systems in rural areas. These sentiments were echoed well by the findings from Chisita (2010) which supported the coordination among service providers to enhance rural ICT development for entrepreneurs.

The desire to maintain status quo: Evidence from studies conducted on ICTs in Zimbabwe have shown that fear of change still grips most rural entrepreneurs in the process robbing them of the right to improve on their business through using modern technology. This paper realizes that the use of computers and cell phones to conduct financial transaction still scares most rural entrepreneurs as they regard these modern devices as the conspiracies of the Western countries to harm them. It may seem to be a narrow minded perspective, but it is a living nightmare among rural entrepreneurs who are resisting change and claiming it is expensive to operate in business using modern technology instead they resort to writing of letters which is a discouragement to the advancement of ICTs in rural areas. These findings correspond with the GEM Report (2011) compiled in South Africa which reveals that, fear of business failure hinders entrepreneurial development. Herrington et al. (2010:49-50) concurs in his study, that the business environment which is factor driven and efficiency driven economies pose unimaginable fear of startup business failure which is a stumbling block for entrepreneurs to explore and experience ICT to increase the chances of business survival. In this regard, ICT companies should strive in their capacity to launch awareness campaigns to engage people in the benefits of using ICT in business for growth and exposure of business on a global scale. To this end, the desire to abandon the status quo can be achieved if the government assists service providers to spread the benefits of technology on how it can generate employment for an economy whose economically active population is suffering. The remoteness of rural entrepreneurs is another contributing factor to the failure of ICT in Zimbabwe. The rural areas of Mhondoro are inaccessible hence service providers and other stakeholders find it difficult infiltrate and establish ICT development as a way of empowering the local communities. Steyn (2013) echoes the same sentiments that the remoteness of entrepreneurs in some communities in South Africa inhibits entrepreneurial growth for rural entrepreneurs.

Insufficient credit/loan facilities: In Zimbabwe the cost of borrowing money from financial institutions and loan sharks scares a lot of entrepreneurs due to the high interests expected in return. Most of such transactions occur in most urban areas. However, such facilities are rarely available in rural areas. This paper establishes that in the Mhondoro district, rural entrepreneurs are faced with this challenge as evidence proves that there is a severe shortage of loan or credit facilities for them to efficiently harness the use of ICT. A report presented by Chisita (2013) in Kenya clarified that lack of finances in business has caused most rural enterprises to lag behind in terms of growth and expansion. These findings correspond to the study conducted by Ihugba et al. (2013) in Nigeria which reveals that entrepreneurs were faced with the challenge of inadequate credit facilities to fund their business operations. Most of the credit borrowing facilities charge exorbitant prices which is a challenge to rural entrepreneurs hence they often fail to grow in business. The FinScope Small Business Survey (2010) corroborates the assertions when it points out that, liquidity crisis is 
one of the severe and most critical; shortcomings for advancing rural entrepreneurship. Based on the findings, rural entrepreneurship using ICT can be achieved if relevant stakeholders and the government collaborate and pump in more funding into the entrepreneurial sector.

Corruption, maladministration in public institutions: Evidence from the study points out that, rampant government corruption has affected every aspect of business, political and socio-economic spectrum in Zimbabwe. In this growing dilemma, rural entrepreneurs are not spared, since they are involuntarily forced to find political affiliations and connections to acquire business opportunities for their enterprises. The payment of bribes, tax evasions and expired business licenses, are the order the day for emerging entrepreneurs who are relegated out of the game due to lack of political affiliation. Most innovative young people with business ambitions especially in the world of entrepreneurship are disadvantaged as a result of unchecked corrupt tendencies either from municipal officials or other government departments. These findings state that endemic corruption in government institution inhibits the growth of ICT; hence rural entrepreneurs still suffer as result of lack of political connections to support their businesses.

Inability to adapt to changing business environment: Through the analysis of secondary data, this paper discovered that the majority of emerging entrepreneurs in rural areas especially Small, Micro, and Medium Enterprises are failing to cope with the changes in the external environment due to irrelevant or lack of information relevant to their business. In several cases when they are problems related to ICT, the rural entrepreneurs lack enough problem solving techniques to survive in the challenging environment. With the fast growing rate of ICT in Zimbabwe, some rural entrepreneurs are failing to cope for instance with the changes in computer software or the use of modern technology to spear head change and enhance their business profits. These findings correspond with a study conducted by Ihugba et al. (2013) in Nigeria which asserts that upcoming entrepreneurs in Nigeria were failing to adapt to the changes in the technological environment which has hampered the ability of their businesses to grow. In most cases when entrepreneurs fail to succeed in starting a business, they give up hope or succumb to psychological trauma associated with high failure rate. A study conducted by Bizri et al. (2012:83) reveals that, most rural entrepreneurs suffer from symptoms inter-arlia personal confidence, low self-esteem and lack of trust. These challenges discourage the advancement of ICT among rural entrepreneurs which is a growing challenge that requires the government and stakeholders to intervene an assist struggling rural entrepreneurs.

Poor planning: Evidence to this paper proves that poor planning among the sponsors of ICT projects has also been a growing challenge which has been passed to most projects in rural areas. For instance various nongovernmental organizations have been sponsoring computer awareness programs in Mhondoro with the aim of equipping the rural entrepreneurs' mostly young people with the necessary technological expertise to exploit the modern devices. However, evidence points out that poor planning and management among the project leaders has hampered the growth of rural entrepreneurs. There is no consistency in the way the technological education and training is provided to the rural people. Sometimes they attend training sessions or miss them due to poor information dissemination. As a result most rural entrepreneurs lag behind on how they should effectively position their business using modern ICT.

Limited youth participation in rural entrepreneurship: Using documentary evidence from Mhondoro District, it has been realized that limited youth participation hinders growth of ICTs in the most vulnerable provinces in Zimbabwe. Despite the ability to grasp internet knowledge most youth still want to focus on using technology only through mobile phones and social networking. Evidence indicates that the growth of Facebook and Whatsapp social networks has robbed the young entrepreneurs of the realization of other eservices from the internet to enable growth of their business. These findings corroborate with the study by Nelson (1997) who notes that despite the availability of ICT projects sponsored by the government, youths are still reluctant to participate in ICT systems are offered. This has been a situation affecting Ghana as Nelson (1997) puts it. The inability of the youth to fully participate in ICT development calls for the government of Zimbabwe and the private sector to launch awareness campaigns on the use of technology to improve the lives of many youths through entrepreneurial development.

Culture and rural entrepreneurship: Cultural belief excludes some groups of people on using ICTs to reduce highest level of poverty in their enterprise. In Mhondoro it has been observed that some conservative 
cultures among the people play a significant role in diminishing the role of ICT advancement. Some rural entrepreneurs are failing to thrive because their cultures or traditional beliefs discourage the use of modern technology to influence economic change. These findings note that these cultural differences fail to promote entrepreneurial development hence various rural areas remained marginalized socio-economically.

Discussion: From the analyses of findings the paper concludes that there is still a wide gap which needs to be filled in terms of ICTs for rural entrepreneurs in Zimbabwe. Despite the proliferation of various technological devices to influence rural economic development, relevant literature suggests that rural entrepreneurs are still facing a myriad of obstacles ranging from financial, political, social and infrastructural. The paper depicts that lack of funding in ICTs towards rural entrepreneurs has crippled various emerging small business to the extent that some have since shut down. The government of Zimbabwe is failing to adequately fund small businesses which are a growing challenge to economically empower the rural people. Evidence from the paper also revealed that it is not only in Mhondoro District but other remote parts of the country which have been affected. The paper establishes that a low educational level among rural entrepreneurs has also been a hindering factor towards achieving effective ICT growth in the communal areas.

The use of cell phones for communication is highly appreciated but there is still a challenge in the use of other technological devices such as computers and scanners among other modern ICT devices. The result is there is little or no education provided by the government and the private sector to enable the best causal relationship between the use of ICT and rural entrepreneurship and consequently, rural entrepreneurs fail to realize the benefits of ICTs. The lack of strategic plans and monitoring and evaluation techniques has also been a backdrop in realizing ICT advancement in Mhondoro. Empirical evidence stressed out that, most ICT projects in rural areas are not monitored by the sponsors be it the government or private sector. This a growing challenge which needs to be addressed urgently because most small businesses are failing to expand because of poor marketing strategies which could be easily done through the internet. The government and the private sector need to collaborate and provide training and development schools to educate the rural entrepreneurs on how to effectively use technology for improving their standards of living. In this sense ICT is a catalyst in improving the image and sustenance of small business in the rural areas of Zimbabwe. The findings have reflected further that that there is a need for increased funding and improved network infrastructure to enhance the use of ICT among rural entrepreneurs.

\section{Conclusion and Recommendations}

The major questions that remain are whether ICT can really be a sustainable option for the rural based entrepreneur? Can ICT advancement in Zimbabwe benefit the rural based entrepreneurs who are involved in small, medium or even micro enterprises for their entrepreneurial developments? For this reason it is essential to note that to promote, sustain and maintain entrepreneurial development, Zimbabwe will require to reach an international standard in terms of ICT policy framework development. To achieve this requirement, there will be need to support and coordinate national ICT research efforts as well as promote the development of software, hardware and ICT infrastructural capacity, particularly for rural based entrepreneurs who do not have adequate access to this infrastructure. The incorporation of ICT in the entrepreneurial development strategies for rural entrepreneurs will definitely have the potential to improve their access to the outside and bigger markets thereby beheading the social construct that rural entrepreneurs are stuck in a cocoon with no room for entrepreneurial development. Policy makers need to promulgate laws that support ICTs in rural entrepreneurship which can be realized through a national budget so that it attracts foreign direct investment as an economic or poverty alleviation initiative. Rural entrepreneurs themselves should adopt team based entrepreneurial activities where they combine their ICT resources to ignite change in their socio-economic inequalities. Despite the high politicization of the study environment, rural entrepreneurs in Zimbabwe need to engage in a mindset shift and denounce the status quo and other cultural beliefs and religious tendencies and embrace the use of ICT, which is currently the only innovative economic strategy to improve their livelihoods at the height of escalating unemployment in Zimbabwe. Public-private partnerships can be formed between the government and private agencies to accelerate ICT implementation in rural areas. Hence, the government of Zimbabwe and relevant stakeholders need to provide mentoring and coaching to rural entrepreneurs which encourages innovativeness and economic transformation. 


\section{References}

Alemna, A. A. \& Sam, J. (2006). Critical Issues in Information and Technologies for Rural Development in Ghana. Information Development, 22, 236-241.

Australian National Audit Office (ANAO). (2009). Innovation in the public sector: Enabling better performance, driving new directions. Canberra: ANAO

Bizri, M. R., Kojok, A., Dani, A., Mokahal, M. \& Bakri, M. (2012). Barriers to entrepreneurial endeavours in a developing economy. World Journal of Social Sciences, 2(6), 79-100.

Chimucheka, T. (2015). The Contribution of Entrepreneurship Education in Improving Entrepreneurial Skills and Knowledge of SMME Owners and Managers. Journal of Economics, 6(2), 149-155.

Chisita, T. C. (2010). An Investigation into the use of ICT in the provision of agricultural information to small farmers in Harare. World Library and information congress: 76th IFLA General Conference and Assemblywww.ifla.org/11/85-chisita-enpdf. Accessed 31 August 2016.

Chisita, T. C. (2013). Renewal and Reinvention: Utilising Information and Communication Technology to Leverage Library Services within the Framework of Library Consortia in Zimbabwe. Presented at SCECSAL XXth Conference hosted by KLA on 4th- $8^{\text {th }}$ June 2012 venue LAICO Regency Hotel Nairobi, Kenya.

Doyle, S. (2008). Essential ICT for A Level. Computer Literacy Press. US.

FINSCOPE. (2010). Survey highlights. South Africa www.finscope.co.za/new/pages/initiatives/countries/south-africa.aspx.n. Date of access: 15 11September 2016.

Fesler, J. W. (1968). Centralization and decentralization. In D.L Sills, (Ed.), International encyclopaedia of the social sciences (pp. 370-379) New York: Macmillan and Free Press.

First National Bank. (2010). The State of Entrepreneurship in South Africa. A white paper by FNB Business Banking. Available online at: www.fnb.co.za [accessed 9 September 2015].

Gambe, T. R. (2015). Stakeholder involvement in water service provision. International Journal of Politics and Good Governance, 11(4), 1-21.

GEM. (2011). Global Entrepreneurship Monitor. Global Report. http://www.gemconsortium.org. Date of access: 10 September. 2016.

Global Entrepreneurship Monitor. (2011). GEM Global Report on GEM surveys entrepreneurs. Geneva: Switzerland.

Government of Zimbabwe. (2012). Government of Zimbabwe Industrial Development Policy 2012- 2016 policy, Government Printers, Harare.

Gore, A. \& Fal, M. (2010). The entrepreneurial dialogues: state of entrepreneurship in South Africa. http://ideate.co.za/entrepreneurial-dialogues-the-state-of-entrepreneurship-in-south-africa-2ndedition/. Accessed 11 September. 2016.

Greneunen, D.V. (2013). Using ICT as a smart enabler of socio economic development. South Africa. Nelson Mandela Metropolitan University- South Africa. Msc-Thesis.

Gunday, G. \& Ulusoy, G. (2011). Effects of innovation types on Firm performance. International journal of production economics, 133(2), 662-676.

Herrington, M., Kew, J. \& Kew, P. (2010). Global entrepreneurship monitors (GEM) South African Report 2010. Cape Town: University of Cape, Graduate School of Business.

Ihugba, A. O., Odii, A. \& Njoku, A. S. (2013). Challenges and Prospects of Entrepreneurship in Nigeria. Academic Journal of Interdisciplinary Studies, 2(5), 25-30.

LSBM. (2016). Working Paper Series 1 (1): 16-20.

Matabvu, D. (2016). Harare postpones prepaid meters, vows introduction is inevitable.

The Sunday Mail, 17 January. Harare: Zimbabwe.

Muzenda, V. \& Machawira, R. (2012). Reporting Period: May 2011 to April 2012 Final Report for Mhondoro Rural Development Project (MRDP). Caritas Zimbabwe Archdiocese Harare.

Ndemo, E. B. (2015). Political Entrepreneurialism: Reflections of a Civil Servant on the Role of Political Institutions in Technology Innovation and Diffusion in Kenya. Stability: International Journal of Security and Development, 4(1), 15.

Nelson, R. E. (1997). Entrepreneurship Education in Developing Countries. Asian Survey, 17(9), 880-885. 
Nhema, L. \& Zinyama, D. (2016). An Assessment of water shortages and coping mechanisms of the residents: A case study of Msasa Park and Dzivarasekwa Extension. IOSR Journal of Agriculture and veterinary sciences, 5(3), 21-35.

Nieman, G. \& Nieuwenhuizen, C. (2009). Entrepreneurship: A New South Africa. $2^{\mathrm{ND}}$ ed. Pretoria: Van Schaik.

Nwagu, E. W. (2006). Integrating ICTs into the Globalization of the poor Developing Countries". Information Development.www.sagepublications.com. Accessed 13 July 2016.

Rasker, R., Gude, P. H., Gude, P. H., Gude, J. A. \& Jeff, V. D. (2009). The economic importance of air travel in high-amenity rural areas. Journal of rural studies, 25 (3), 343- 353.

Rogers, E. M. (1995). Diffusion of innovations. New York: Free Press.

Sanders, T. (2008). Mobile phone use and policy in Southern Africa Sauti. Stanford Journal of African Studies, 2(8).

Steyn, J. (2013). Public and private access to ICTs in developing regions. Proceedings of the 7th International Development Informatics Association Conference, held in Bangkok, Thailand. Pages 1-10.

Timmons, J. \& Spinelli, S. (2004). New Venture Creation Entrepreneurship for $21^{\text {st }}$ Century. 6th ed. s.l.:McGraw Hill.

World Bank. (2012). Information and Communications for Development: Maximizing Mobile. Washington, D.C.

World Bank (2013). World Development Report: Jobs. ITU, Measuring the Information Society. Geneva: ITU.

WB (World Bank's World Development Indicators). (2015). Zimbabwe: Selected Issues and Statistical Appendix. Harare: Zimbabwe.

Zimbabwe National ICT policy Framework Review. (2012). Ministry of Information and Communication Technology. Www.ictministry.gov.zw. Accessed 09 August 2016.

Zimmerman, J. (2008). The role of design artefacts in design theory construction. Artefact: Journal of Virtual Design, 2(1), 41-45. 